\title{
Improving Knowledge and Changing Health Attitude among Teenagers through Digital Media Flipbook
}

\author{
Erni Gustina ${ }^{1}$, Marsiana Wibowo ${ }^{2}$ \\ ${ }^{1}$ Public Health, Universitas Ahmad Dahlan, Indonesia \\ Email: erni.gustina@ikm.uad.ac.id \\ ${ }^{2}$ Public Health, Universitas Ahmad Dahlan, Indonesia \\ Email: marsianawibowo@ikm.uad.ac.id
}

\begin{abstract}
(Received: December-2019; Reviewed: January-2020; Accepted: February-2020; Available online: February 2020; Published: April-2020)
\end{abstract}

\begin{abstract}
The aims in this study to analyze the effectiveness of digital flipbooks as a medium for health promotion for adolescents. This study is a quasi experimental design with a One Group Pre and Post Test Design. The sample of this study was 100 adolescents. The average age of adolescents was 16 years and the majority of the female sex. Mean rank for knowledge (Mean rank=2.86; $p$-value $=0.24$ ) and attitude (Mean rank=11.8; $p$-value = 0.009). Digital media flipbook can influence the attitudes of adolescents but does not affect the change of knowledge. Increase exposure to health promotion programs by expanding access to information about preventing risk behaviors in adolescents to maintain attitudes that avoid adolescents risk behavior.
\end{abstract}

Keywords: Digital Media; Flipbooks; Knowledge; Attitudes; Adolescents.

\section{INTRODUCTION}

Media has multiple meanings, both seen limited or extensive (Parvanta, Nelson, Parvanta, $\&$ Harner, 2011). Selection of the media must be adapted to the characteristics of the target, such as a teenager. Most adolescents access reproductive health information over the Internet from their smartphone. Teens consider the internet is a major source of information for them (Ardina, 2017). However, there is concerns from the information obtained, the accuracy of the information as the information is a hoax or not and semantic barriers in the form of scientific terms that are poorly understood (Prasanti, 2017). The effects of these media are multifactorial and depend on the type, usage, and amount of media and the characteristics of each user, such as children and adolescents (Chassiakos et al., 2016). Media exposure to sexual content often pose risks such as premature sexual (O'Hara, Gibbons, Gerrard, Li, \& Sargent, 2012) and sexual violence (Ybarra, Strasburger, \& Mitchell, 2014). But the media also able to have a positive effect in improving sexual health in adolescents as well as increasing knowledge about risk factors and prevention of HIV/STD (Divecha, Divney, Ickovics, \& Kershaw, 2012; Gabarron \& Wynn, 2016; Wadham, Green, Debattista, Somerset, \& Sav, 2019).

Digital media has the extraordinary potential of engaging and supporting adolescent reproductive health (Guse et al., 2012). Media development as health and welfare interventions need to be promoted to the youth so that the media have a positive impact and effective for adolescents (Collins et al., 2017; Cookingham \& Ryan, 2015) and protects adolescents from the negative potential of the media (Romer \& Moreno, 2017). Media that have been developed must be publicly accessible to both health care providers (Cookingham \& Ryan, 2015) and parents so that their children use the media for things that are important for health growth and 
development (Chassiakos et al., 2016).

Health promotion using media has great potential and has potential as a means of monitoring young people such as setting targets, increasing self-monitoring and awareness (Dute, Bemelmans, \& Breda, 2016). Social media (Chassiakos et al., 2016; Welch, Petkovic, Pardo Pardo, Rader, \& Tugwell, 2016), Mobile phones (L'Engle, Mangone, Parcesepe, Agarwal, \& Ippoliti, 2016), smartphone applications (Wu et al., 2018), new media intervention (Wadham et al., 2019), digital health intervention is widely used as a medium for health promotion to improve the health and well-being of adolescents. But the effectiveness of the media requires more research (Welch et al., 2016). Reference books on adolescent reproductive health have been developed, but references that are easy to read, inexpensive, and in accordance with the development and problems of adolescents are still rarely found. A complete, concise reference, answering adolescent health problems and proven effectiveness is very important to be created. The reference is in the form of a digital flip book application that can be installed on teen smartphones. Digital flipbooks have been widely developed in the world of education (Pornamasari, 2017; Rohman, Admoko, Fisika, \& Surabaya, 2017; Setyawati \& Herlambang, 2015; Wahyuliani, 2016), but specifically reproductive health targeting adolescents is difficult to find.

We have been developing digital media content flipbook with premarital sexual behavior, violence and early marriage that has a health impact on teenagers. We have tested the media for validity by material experts and media experts. Digital media flipbook "Me: Teenagers and My Health" which can be accessed on android in the form of applications. Apps that contain adolescent health content into a valuable resource for learning about comprehensive adolescent health (Brayboy et al., 2017). The selection of digital flipbooks is also adjusted to the characteristics of teenagers who have very easy access to smartphones (Aschbrenner et al., 2019) and the closeness of adolescents to the internet through their smartphones (Dunlop, Freeman, \& Jones, 2016; Wartella, Rideout, Montague, Beaudoin-Ryan, \& Lauricella, 2016). This study aimed to analyze the effectiveness of digital flipbooks as a medium for health promotion to improve knowledge and attitude among adolescents.

\section{METHOD}

This study is a quasi experimental design with a One Group Pre and Post Test Design where each experimental unit functions as a control for themselves and observations of outcome variables are made before and after treatment. The treatment effect is determined by comparing the values of the outcome variables after and before the treatment that occurs in groups. The sample of this study was adolescents aged 15-19 years taken from 5 High Schools in the Yogyakarta City Region. The sample size in this study was 100 adolescents. Data were collected with the following steps: 1) students fill out the questionnaire as a pre-test results; 2) conduct experimental material by providing flipbooks digital media; 3) do posttests to students.

\section{RESULT AND DISCUSSION}

\section{Result}

This study involved 100 teenagers aged 15-19 years from 5 High Schools. The average age of adolescents is 16 years and the majority of the female sex (Table 2). Adolescents have relatively the same knowledge before and after being given a digital flipbook, but and the attitude of teenagers before and after being given a digital flipbook is different (Table 3). The results of the bivariate analysis showed that the knowledge and attitudes of adolescents had a difference in value before and after being given digital media flipbook. But statistically, only attitudes that have different attitudes before and after the provision of digital media flipbook as a media for health promotion (Table 4). 
Table 1. Respondents Characteristics based on gender dan age

\begin{tabular}{lcc}
\hline Characteristics & Frequency $(\mathbf{n = 1 0 0})$ & Percentage $(\boldsymbol{\%})$ \\
\hline Gender & 34 & 34.00 \\
Male & 66 & 66.00 \\
Female & 12 & 12.00 \\
\hline Age & & 60.00 \\
15 years old & 60 & 28.00 \\
16 years old & 28 & \\
17 years old & &
\end{tabular}

Table 2. Frequency distribution of knowledge and attitude among adolescents

\begin{tabular}{lcccc}
\hline Variables & \multicolumn{2}{c}{$\begin{array}{c}\text { Pretest } \\
\text { Frequency }\end{array}$} & $\begin{array}{c}\text { Postest } \\
\text { Percentage (\%) }\end{array}$ \\
\hline Knowledge & & & Frequency & \\
High & 29 & 29.00 & 30 & 30.00 \\
Lowi & 71 & 71.00 & 70 & 70.00 \\
\hline Attitude & 45 & 45.00 & 49 & 49.00 \\
Negative & 55 & 55.00 & 51 & 51.00 \\
Possitive & & & \\
\hline
\end{tabular}

Table 3. The result of statistical of effectivitas digital media book improved knowledge and attitude

\begin{tabular}{lcc}
\hline Variable & Mean Rank & P-value \\
\hline Knowledge & & \\
Pretest & 35.35 & 0.24 \\
Postest & 38.21 & \\
\hline Attitude & & 0.009 \\
Pretest & 40.27 & \\
Postest & 52.27 & \\
\hline
\end{tabular}

\section{Discussion}

This research was conducted with the aim of seeing the impact of digital media delivery as an intervention to increase knowledge and attitudes of adolescents. Digital flipbook intervention gives a different mean score of knowledge before and after the intervention but does not have a significant effect on changes in respondents' knowledge. But interventions using a digital flipbook have a significant effect on changing attitudes which changes in a person's attitude can occur even if there is no change in one's cognitive structure. Changes in attitudes that occur in respondents caused by peripheral cue present, i.e. respondents get a strong influence from what is around them. However, the attitude that is formed is still temporary, vulnerable, and unexpected (Prestwich, Kenworthy, \& Conner, 2018).

Changing attitudes and behavior begins with persuasive communication using a digital flipbook about risk behaviors in adolescents that have an impact on health. Teenagers need information, skills, and commitment to get optimal health outcomes (Temple-Smith, Moore, \& Rosenthal, 2016). The messages in the digital book are carefully developed in accordance with the current conditions of adolescent risk behavior and how their preventive actions are referred to as the systematic route (Prestwich et al., 2018).

Adolescent problems such as adolescent sexual behavior, alcohol use (Romer \& Moreno, 2017) are increasingly informed through messages in the media. Media literacy interventions have a positive influence on adolescent attitudes and intentions towards risky sexual behavior, smoking, and drug use (Vahedi, Sibalis, \& Sutherland, 2018). Social media offers an easily accessible place for health interventions in groups with poor health risks (HudnutBeumler, Po'e, \& Barkin, 2016). Transmission of 
clear and factual and comprehensive sexual health information can be easily accessed using a smartphone application (Brayboy et al., 2017).

New electronic media have a big positive impact on society, but also have a negative side which is a public health problem (David-Ferdon \& Hertz, 2007). Cellular technology and social media have changed the social landscape and communication of people and organizations. This cellular technology takes the principle of community mobilization, which is to facilitate critical awareness and empower people to drive change. Community mobilization programs must utilize the latest technology in cellular technology such as new social media that has changed the way individuals interact with health information (Nutland, 2015). Teenagers need education programs for smart internet use and recovery from addiction to internet use with digital applications (Mutimmatul, Wibawa, \& Ekawati, 2018). One of the newest media is applications that can be downloaded at Play store on smartphones (Lupton, 2015). Urban communities seek and obtain information including through online media/website portals that are credible about health information, and social media in the form of sharing info from WhatsApp Group, LINE Group, and BBM Group (Prasanti, 2017). Researchers pay attention to this phenomenon as an opportunity to be able to interact with the public, especially teenagers about health information using applications in their smartphones, such as what informants have said that adolescent technology is based on Android and social media, so that it is in accordance with the times.

The study results show that the "Me: Teenagers and My Health" flipbook digital media is an interesting medium. This media can increase adolescent knowledge about risk behavior in adolescents that have an impact on their health. Biopsychosocial factor models in taking risk behaviors in adolescents are influenced by cognitive factors namely egocentric characteristics and future perspectives of adolescents and perceptions of adolescents related to their health behaviors (Strasburger, Jordan, \& Donnerstein, 2009). Media exposure significantly influences the risk behavior of sexually transmitted diseases in street children (Subekti, Demartoto, \& Prayitno, 2016) and differences in sexual behavior in urban and rural areas (Umaroh, Kusumati, \& Kasjono, 2015).

The results of this study indicate that there is an increase in the value of attitudes before and after teens learn digital flipbooks. This digital flipbook significantly influences adolescent attitudes toward health behaviors. Teenagers have positioned electronic media as a source of information over oral and print media. Adolescent access to information resources influences their attitudes in health practice. Digital media flipbook has been widely developed and can be used to improve higherorder thinking skills (Arini \& Kustijono, 2017) and provide better learning outcomes than textbooks (Budi Santoso, Siswandari, \& Sawiji, 2018; Wijayanto \& Saifuddin Zuhri, 2014). Digital media distributed through schools will reduce public concerns about the accuracy of information sources because the current source of information is more obtained through online media where the trustworthiness of the contents of the information is still questioned (Prasanti, 2017).

The researcher hopes that the media created and distributed by researchers will be able to become one of the programs of schools that provide positive outcomes for their students, because there have been many school-based health education programs that have successfully provided positive student outcomes (BahrerKohler \& Carod-Artal, 2017) such as interactive flipbooks for social studies subjects (Solikhatun $\&$ Widihastrini, 2017). Digital book media can be used independently to improve students' understanding. An interesting digital book consists of the display of text, images, audio, the video that allows students to understand the material presented (Aulia, Patmantara, \& Handayani, 2016).

Researchers have developed a digital flipbook with attractive text and image illustrations, without audio and video. Through assessments by experts and limited objectives, this media has been declared worthy of use and tested on broader targets (Wibowo, Gustina, Ayu, $\&$ Sofiana, 2019). However, in this intervention study the results were found the layout of the colors and the illustrations get input for more optimal results from the informants. Suggestions for improvement are needed by researchers to improve the media so that it is more feasible to be published to adolescents and hopes can be used as teaching materials in schools in promoting health for adolescents, especially in overcoming risky behavior in adolescents. 


\section{CONCLUSSION AND SUGGESTION}

Flip Book Digital Media is capable of influencing adolescents' attitudes but have no effect on knowledge change. It's necessary to increase exposure to health promotion programs by expanding access to information about preventing risk behavior in adolescents to maintain risk attitudes.

\section{REFERENCE}

Ardina, M. (2017). Akses Informasi Kesehatan Reproduksi. Komunikator, 9(1), 17-24. Retrieved from http://journal.umy.ac.id/index.php/jkm/arti cle/view/2678/2683

Arini, D., \& Kustijono, R. (2017). The Development of Interactive Electronic Book (BUDIN) Using Flip PDF Professional to Train Higher Order Thinking Skills. Jurnal Inovasi Pendidikan Fisika, 06(03), 323-328.

Aschbrenner, K. A., Naslund, J. A., Tomlinson, E. F., Kinney, A., Pratt, S. I., \& Brunette, M. F. (2019). Adolescents' use of digital technologies and preferences for mobile health coaching in public mental health settings. Frontiers in Public Health, 7(JUL), 1-9. https://doi.org/10.3389/fpubh.2019.00178

Aulia, R., Patmantara, S., \& Handayani, A. N. (2016). PERANCANGAN BUKU DIGITAL INTERAKTIF BERBASIS FLIPPING BOOK TIK KELAS XI SMA. Prosiding SENTIA 2016, 8(1), 346-351. Retrieved from http://sentia.polinema.ac.id/index.php/SEN TIA2016/article/view/66/61

Bahrer-Kohler, S., \& Carod-Artal, F. (2017). Global Mental Health: Prevention and Promotion. In S. Bahrer-Kohler \& J. CarodArtal, Francisco (Eds.), Springer. Switzerland: Springer International Publishing.

Brayboy, L. M., Sepolen, A., Mezoian, T., Schultz, L., Landgren-Mills, B. S., Spencer, N., .. Clark, M. A. (2017). Girl Talk: A Smartphone Application to Teach Sexual Health Education to Adolescent Girls. Journal of Pediatric and Adolescent
Gynecology, 30(1), 23-28. https://doi.org/10.1016/j.jpag.2016.06.011

Budi Santoso, T. N., Siswandari, S., \& Sawiji, H. (2018). The Effectiveness of eBook versus Printed Books in the Rural Schools in Indonesia at the Modern Learning Era. International Journal of Educational Research Review, 3(4), 77-84. https://doi.org/10.24331/ijere.453512

Chassiakos, Y. R., Radesky, J., Christakis, D., Moreno, M. A., Cross, C., Hill, D., ... Swanson, W. S. (2016). Children and adolescents and digital media. Pediatrics, 138(5). https://doi.org/10.1542/peds.20162593

Collins, R. L., Strasburger, V. C., Brown, J. D., Donnerstein, E., Lenhart, A., \& Ward, L. M. (2017). Sexual media and childhood wellbeing and health. Pediatrics, 140, S162S166. https://doi.org/10.1542/peds.2016$1758 \mathrm{X}$

Cookingham, L. M., \& Ryan, G. L. (2015). The impact of social media on the sexual and social wellness of adolescents. Journal of Pediatric and Adolescent Gynecology, 28(1), 2-5. https://doi.org/10.1016/j.jpag.2014.03.001

David-Ferdon, C., \& Hertz, M. F. (2007). Electronic Media, Violence, and Adolescents: An Emerging Public Health Problem. Journal of Adolescent Health, 41 (6UPPL.), 1-5. https://doi.org/10.1016/j.jadohealth.2007.0 8.020

Divecha, Z., Divney, A., Ickovics, J., \& Kershaw, T. (2012). Tweeting About Testing: Do Low-Income, Parenting Adolescents And Young Adults Use New Media Technologies To Communicate About Sexual Health? Perspectives on Sexual and Reproductive Health, 44(3), 176-183. https://doi.org/10.1363/4417612

Dunlop, S., Freeman, B., \& Jones, S. C. (2016). Marketing to youth in the digital age: The promotion of unhealthy products and health promoting behaviours on social media. Media and Communication, 4(3), 35-49. https://doi.org/10.17645/mac.v4i3.522

Dute, D. J., Bemelmans, W. J. E., \& Breda, J. 
(2016). Using Mobile Apps to Promote a Healthy Lifestyle Among Adolescents and Students: A Review of the Theoretical Basis and Lessons Learned. JMIR MHealth and UHealth, 4(2), e39. https://doi.org/10.2196/mhealth.3559

Gabarron, E., \& Wynn, R. (2016). Use of social media for sexual health promotion: A scoping review. Global Health Action, 9(1). https://doi.org/10.3402/GHA.V9.32193

Guse, K., Levine, D., Martins, S., Lira, A., Gaarde, J., Westmorland, W., \& Gilliam, M. (2012). Interventions using new digital media to improve adolescent sexual health: A systematic review. Journal of Adolescent Health, 51(6), 535-543. https://doi.org/10.1016/j.jadohealth.2012.0 3.014

Hudnut-Beumler, J., Po'e, E., \& Barkin, S. (2016). The Use of Social Media for Health Promotion in Hispanic Populations: A Scoping Systematic Review. JMIR Public Health and Surveillance, 2(2), e32. https://doi.org/10.2196/publichealth.5579

L'Engle, K. L., Mangone, E. R., Parcesepe, A. M., Agarwal, S., \& Ippoliti, N. B. (2016, September 1). Mobile phone interventions for adolescent sexual and reproductive health: A systematic review. Pediatrics, Vol. 138. https://doi.org/10.1542/peds.2016-0884

Lupton, D. (2015). Health promotion in the digital era: A critical commentary. Health Promotion International, 30(1), 174-183. https://doi.org/10.1093/heapro/dau091

Mutimmatul, F., Wibawa, S. C., \& Ekawati, R. (2018). Digital Addiction in Indonesian Adolescent. Advances in Intelligent Systems Research (AISR), 274-277. https://doi.org/10.2991/miseic-18.2018.66

Nutland, W. (2015). Using media to promote health: mass media, social media, and social market ing. In W. Nutland \& L. Cragg (Eds.), Health Promotion Practice (Second Edi). UK: Open Universiity Press.

O'Hara, R. E., Gibbons, F. X., Gerrard, M., Li, Z., \& Sargent, J. D. (2012). Greater Exposure to Sexual Content in Popular Movies Predicts Earlier Sexual Debut and
Increased Sexual Risk Taking. Psychological Science, 23(9), 984-993. https://doi.org/10.1177/095679761143552 9

Parvanta, C., Nelson, D., Parvanta, S., \& Harner, R. (2011). Essentials of Public Health Communication (R. Riegelman, Ed.). USA: Jones \& Bartlett Learning.

Pornamasari, E. I. (2017). Pengembangan Modul peembelajaran Berbantu Flipbook maker dengan Model Pembelajaran Numbered Heads Together (NHT) Berbasis Teori Vygotsky Materi Pokok Relasi dan Fungsi. Jurnal Pendidikan Matematika, 1(1), 7483. Retrieved from http://journal.upgris.ac.id/index.php/aksio $\mathrm{ma} /$ article/viewFile/1412/1211

Prasanti, D. (2017). The Portrait of Media Health Information For Urban Community in The Digital Era. IPTEK-KOM, 19(2), 149-162. Retrieved from https://media.neliti.com/media/publications /228091-potret-media-informasikesehatan-bagi-ma-2319a661.pdf

Prestwich, A., Kenworthy, J., \& Conner, M. (2018). Health behavior change: theories, methods and interventions. Retrieved from http://library1.org/_ads/5E4AE9DFE738D D93B92A2B2AABCB6A7E

Rohman, A. A., Admoko, S., Fisika, J., \& Surabaya, U. N. (2017). The Development Of Interactive Electronic Book (Budin) Using Flip Pdf Professional To Train Higher Order Thinking Skills. Jurnal Inovasi Pendidikan Fisika (JIPF), 06(03), 323-328. Retrieved from https://jurnalmahasiswa.unesa.ac.id/index. php/inovasi-pendidikanfisika/article/download/21800/19988

Romer, D., \& Moreno, M. (2017). Digital media and risks for adolescent substance abuse and problematic gambling. Pediatrics, 140(November 2017), S102-S106. https://doi.org/10.1542/peds.2016-1758L

Setyawati, V. A. V., \& Herlambang, B. A. (2015). Model Edukasi Gizi Berbasis Ebooklet untuk Meningkatkan Pengetahuan Gizi Ibu Balita. Jurnal Informatika Upgris, l(1 Juni), 86-94. 
https://doi.org/10.26877/JIU.V1I1

JUNI.810

Solikhatun, R., \& Widihastrini, F. (2017). The Development Of Interactive FlipbookFormed Teaching Material To Improve The Of Grade 4 Students ' Social Science Learning Outcomes. The Journal of Elementary School Teacher Training and Pedagogy, 2(2), 83-89. Retrieved from https://journal.unnes.ac.id/nju/index.php/es t/article/download/16802/8468

Strasburger, V. C., Jordan, A. B., \& Donnerstein, E. (2009). Health Effects of Media on Children and Adolescents. Pediatrics, 125(4), 1-14. https://doi.org/10.1542/peds.2009-2563

Subekti, Y. Y., Demartoto, A., \& Prayitno, A. (2016). Pengaruh Jenis Kelamin, Pajanan Media, Peran Teman Sebaya, Pengetahuan Penyakit Menular Seksual, Kedekatan Keluarga Terhadap Perilaku Berisiko Penyakit Menular Seksual Pada Anak Jalanan. JURNAL PERMATA INDONESIA, $7(2), \quad 24-33 . \quad$ Retrieved from http://www.permataindonesia.ac.id/wpcontent/uploads/2017/04/Vol.-7-No.-2Yulia-Yekti-Subekti.pdf

Temple-Smith, M., Moore, S., \& Rosenthal, D. (2016). Sexuality in Adolescence: The Digital Generation. In Sexuality in Adolescence: The digital generation. https://doi.org/10.4324/9781315849348

Umaroh, A. K., Kusumati, Y., \& Kasjono, H. S. (2015). Hubungan antara Faktor Internal dan Faktor Eksternal dengan Perilaku Seksual Pranikah Remaja di Indonesia. Jurnal Kesehatan Masyarakat Andalas, 6575.

Vahedi, Z., Sibalis, A., \& Sutherland, J. E. (2018). Are media literacy interventions e ff ective at changing attitudes and intentions towards risky health behaviors in adolescents? A meta- analytic review. Journal of Adolescence, 67(February), 140-152.

https://doi.org/10.1016/j.adolescence.2018. 06.007

Wadham, E., Green, C., Debattista, J., Somerset, S., \& Sav, A. (2019). New digital media interventions for sexual health promotion among young people: A systematic review. Sexual Health, Vol. 16, pp. 101-123. https://doi.org/10.1071/SH18127

Wahyuliani, Y. (2016). Efektivitas Penggunaan Media Pembelajaran Flip Book Terhadap Peningkatan Hasil Belajar Siswa Pada Mata Pelajaran Pai Dan Budi Pekerti Di Sma Negeri 4 Bandung. Tarbawy, 3(1), 22-36. Retrieved from http://ejournal.upi.edu/index.php/tarbawy/a rticle/download/3457/2443

Wartella, E., Rideout, V., Montague, H., Beaudoin-Ryan, L., \& Lauricella, A. (2016). Teens, health and technology: A national survey. Media and Communication, 4(3), 13-23. https://doi.org/10.17645/mac.v4i3.515

Welch, V., Petkovic, J., Pardo Pardo, J., Rader, T., \& Tugwell, P. (2016). Interactive social media interventions to promote health equity: An overview of reviews. Health Promotion and Chronic Disease Prevention in Canada, Vol. 36, pp. 63-75. https://doi.org/10.24095/hpcdp.36.4.01

Wibowo, M., Gustina, E., Ayu, S. M., \& Sofiana, L. (2019). Digital Flipbook Media as a Media for Health Promotion in Youth: Research and Development. International Journal of Educational Research Review, 4, 725-733. https://doi.org/10.24331/ijere.628717

Wijayanto, \& Saifuddin Zuhri, M. (2014). Pengembangan E-Modul Berbasis Flip Book Maker Dengan Model Project Based Learning Untuk Mengembangkan Kemampuan Pemecahan Masalah Matematika. Prosiding Mathematics and Sciences Forum, 625-628. Retrieved from http://prosiding.upgris.ac.id/index.php/mas if2014/masif2014/paper/viewFile/487/436

Wu, Y. P., Linder, L. A., Kanokvimankul, P., Fowler, B., Parsons, B. G., MacPherson, C. F., \& Johnson, R. H. (2018). Use of a smartphone application for prompting oral medication adherence among adolescents and young adults with cancer. Oncology Nursing Forum, 45(1), 69-76. https://doi.org/10.1188/18.ONF.69-76 
22 | Vol 6 No 1, April 2020

Ybarra, M. L., Strasburger, V. C., \& Mitchell, K.

J. (2014). Sexual media exposure, sexual behavior, and sexual violence victimization in adolescence. Clinical Pediatrics, 53(13), 1239-1247.

https://doi.org/10.1177/000992281453870 0 